\title{
Factors Affecting Employees' Performance: A Case of Kabul-Based Telecom Firms
}

\author{
Syed Umar Farooq ${ }^{1}$, Muhammad Shahid Shams ${ }^{2}$, Murtaza M. Niazi ${ }^{3}$
}

Abstract

This study synthesizes the body of literature on employees' performance and develops a conceptual framework that depicts plausible impacts of employees' participation, job involvement, and employees' relations on employees' performance. Herzberg two-factor theory is considered for this study as a theoretical anchor. To test the model, the study uses a sample of 200 employees working in Kabul-based telecom firms. The study finds a positive and significant impact of employees' participation, job involvement, and employer-employees relations on employees' performance. This research will help managers in the telecom sector to understand ways to enhance employees' performance by having an insight of the factors affecting it.

Keywords: Employee performance, job involvement, employees' relations, employees' participation

\section{Introduction}

Managing employees' performance has always been a challenging task for managers in organizations; especially in developing countries like Afghanistan. Employee performance is considered as the product of ability and motivation and managers have always tried to motivate employees to bring the best out of them (Moorhead \& Griffin, 1998). To improve employees' performance, managers use both financial and non-financial rewards as means to motivate employees in the organization. Panagiotakopoulos (2013), and Lavelle, Gunnigle, and McDonnell (2010) argued that financial rewards and equality in the level of motivation are the key factors to improve employees performance in organizations. Many studies confirm a strong correlation between employee satisfaction and performance. With the monetary awards, the non-monetary rewards are also used as effective tools for achieving employee satisfaction. Extensive literature is available on the non-financial rewards and employee satisfaction (Praga, 2008). Another study by Dambisya (2007) investigated the use of non-monetary rewards for achieving employees' satisfaction in the health sector. The study confirmed the effect of non-monetary rewards and employee satisfaction. Similarly, the study by John (2009) established the relationship between non-financial rewards and work-

1 Abasyn University Peshawar, email: syed.umarfarooq@abasyn.edu.pk

2 Kardan University, Kabul

3 Kardan University, Kabul 
ers' satisfaction. Hence, an effective reward package (nonfinancial) is requisite for motivating employees which results in their job performance. In short, non-financial rewards motivate employees; motivation results in satisfaction, and satisfaction leads to better employee performance. This study focuses on the use of incentives other than monetary in nature, like employer-employees' relations, employees' participation and job involvement to enhance employees' performance in the Telecom sector.

Based on the long-term personal working experience with some of the organizations in Afghanistan, the author has observed that majority of the managers use centralization in their management practices. Perhaps the culture of respect for seniors and obedience has affected the decision making style in organizations. This assumption can be supported by Mujtaba and Kaifi (2008). They categorically mentioned in their study the difference of leadership orientation towards tasks and relationship between Afghan and American professionals' that the culture of Afghanistan has traditionally emphasized hierarchy, paternalism, and mastery in contrast to egalitarianism, autonomy and harmony. Consequently, this provides rationale to conduct the current study. This study shall help managers employed in the Telecommunication as well as other sectors of the economy to understand the importance of non-monetary rewards such as participation, job involvement and employee relations, as sources of motivation for employees, which would result in higher employee performance.

\section{Literature Review}

\subsection{Employee Performance}

Hellriegel and Slocum (1999) define performance as a consequence of the efforts employed by people in the organization at different levels. These efforts resultantly lead to achieving goals and improved organizational performance (Armstrong \& Baron, 1998).

Organizational performance is entirely based on employees' performance, i.e. better the employees' performance, higher the organizational performance and vice versa. A strong correlation is reported between employees' performance and performance of the organization (see Collis \& Montgomery, 1995; Mwita, 2000; Abbas \& Yaqoob, 2009). Armstrong and Baron (1998) also reported a strong positive correlation between employees' performance and organization's productivity and growth.

Although performance is an individual manifestation, it ties up with variables like ability and motivation affecting it the most (Cummings \& Schwab, 1973; Whetten \& Cameron 1998). To undertake this research, a well-known two-factor theory developed by Herzberg in 1959 is taken as a theoretical base. This theory describes two factors; 
one of them is a motivator and the other one is hygiene factor. 'Motivators' are intrinsic motivational factors such as challenging work, recognition for one's achievement, responsibility, opportunity to do something significant (job involvement), contribution in decision-making, sense of importance to an organization etc. On the other hand hygiene factors are extrinsic motivational factors such as company policy, supervisory relationship with boss (employee relations), work conditions, salary, relationship with peers, security etc. The presence of motivators can lead to satisfaction and the absence of hygiene factors can lead to dissatisfaction. However, an important point is that these two factors cannot be considered as opposite to each another.

In the present study, job involvement and participation in decision making are considered as motivators, and employee relations as a hygiene factor to see their effect on employee performance in the Telecom sector.

\subsection{Employee Participation}

Locke and Schweiger (1979) define employee participation as an influence sharing process among employees who are not at the same hierarchical level. Managers and subordinates are equally involved in organization's affairs like problem solving, information sharing and decision making by undertaking the participative management practices (Wagner, 1994). Another broader definition given by Beardwell and Claydon (2007) is that employee participation exhibits the division and use of power not only between the owners and managers but by the people employed by them in the organization. This definition covers all the direct and indirect involvement of employees associated with the socio-technological and political structures of the organization in the decision making process. Here, the indirect involvement is decision-making which refers to involving representative working in broader organizational structure. In addition to this, Luthans (2005) describes the involvement of employees intellectually, emotionally and physically in all the formal and informal decisions of the firm which, according to Graham and Bennet (1998), means that employees will be provided with all sufficient information for consultation and negotiation for any decision made and executed.

The concept of employee participation, nowadays, is a matter of grave interest for majority of the employers as it possibly results in enhancing employee performance, improving their morality, and eventually leading to higher job satisfaction (Likert, 1961; Wilpert, 1998; Markey, 2001). Based on the literature, a positive result is expected between employee participation and employee performance. Hence our first proposed hypothesis for this study is:

$\mathrm{H}_{1}$ : There is a significant positive relationship between employee participation 
and employee performance in the Telecom sector of Afghanistan.

\subsection{Employer-Employees’ Relations}

Employee relations means the way managers interact with their employees. For higher performance and lower absenteeism, socialization and interaction can be of great help (Padilla-Velez, 1993). Thus, the relationship between employers and employees needs to be cordial for an effective communication and efficient performance. Employee relations have a great influence on the success of the entire company. Therefore, the creation and reconciliation of internal relations among employees of different departments are very important for the successful operations in a company and for the improved performance of employees (Ahmed \& Rafiq, 2003). Moreover, Ahmed and Rafiq (2003) argue that in an organization, through understanding and confidentiality, trust and loyalty help in achieving good relations.

ALDamoe (2015) posits that a well maintained employee relations serves three purposes to the organization. First, it helps in tackling and administering the conflict at the work place, hence minimizing the disruptive behavior. Second, it assists employers to be able to identify and avoid conflicts ahead of time which helps employees focus on their professional development, and also support organizational goals. Third, and above all, it creates a culture that considers the interest and wellbeing of employees.

In the light of said literature, a positive relationship between employee relations and employee performance is expected; therefore, we propose our second hypothesis as:

$\mathrm{H}_{2}$ : There is a significant positive relationship between employee relations and employee performance in the Telecom sector of Afghanistan.

\subsection{Job Involvement}

Job involvement signifies the amount of an employee's psychological connection with his/her job (Kanungo, 1982). It indicates a cognitive attachment and his/her concerns about the job (Paullay, Alliger, Stome, \& Eugene, 1994).

Job involvement encompasses the sense of controlling one's work, getting performance feedback, and being compensated for the overall good performance of the organization (Lawler, Mohrman, \& Ledford, 1992). Their study concluded on revealing the advantages of designing job involvement programs. Therefore, managers have to initiate job involvement activities in the organization and these activities should further be linked up with the performance evaluations and compensation systems. Employees upon receiving benefits from the organization try to reciprocate it through their on-job performance. 
Employee involvement results in low absenteeism, low turnover, good performance and job satisfaction (Brown, 1996). Soong (2000) also testified a strong relationship between job involvement and job satisfaction. In the broad spectrum, employee involvement is considered to be a key determinant of organizational productivity (Pfeffer, 1994).

On the basis of above literature, a positive relationship is expected between job involvement and employee performance, leading to propose our third hypothesis of the study as:

$\mathrm{H}_{3}$ : There is a significant positive relationship between Job involvement and employee performance in the Telecom sector of Afghanistan.

Employee performance is taken as dependent or input variable while employee participation, employee relations, and job involvement are presented as independent variables.

\section{Methodology}

\subsection{Research Design}

A questionnaire comprising of questions on a 5-point Likert scale (attached at the appendix) was used as a descriptive survey design to collect information for this study. Descriptive surveys are intended to gather comprehensive and factual information to outline an on-hand phenomenon (Ezeani, 1998).

Scale points were labeled as: $5=$ Strong Agree $(\mathrm{SA}), 4=$ Agree $(\mathrm{A}), 3=\operatorname{Neutral}(\mathrm{N})$, $2=$ Disagree $(\mathrm{DA}), 1=$ Strongly Disagree $(\mathrm{SDA})$.

\subsection{Research Participants}

Research participants were selected from the Telecom companies operating in Afghanistan. According to Afghanistan Telecom Regularity Authority (ATRA), currently there are six mobile telephone operators namely AWCC (Afghan Wireless Communication company), Roshan, AFTEL (Afghan Telecom), Wesal Telecom, Etisalat, and MTN. Convenience sampling method, which is one of the types of non-probability sampling technique (Marshal \& Ward, 1996), was employed for the sample selection. The reasons behind using convenience sampling technique were accessibility to the selected organizations and employees working in those organizations, employees' availability in working hours, their willingness to provide information, and above all, the prevailing security situation in the overall region. These were some of the limitations of the present study also. 
As a whole, data were collected from 200 participants working in the Kabul based branches of the above-mentioned organizations. Tabular information about the number of participants selected from each organization is provided in the appendix. Keeping in view the nature of the study, employees working in human resource department and other officer level staff involved in planning and development issues were selected for the data collection. This is because human resource department deals with the issues related to employees like performance appraisal, training and development, employee relation and grievances etc. Officer level staff involved in planning and development activities were identified by the human resource department in above mentioned organizations.

\subsection{Procedure}

To comprehend views of the employees working in all six different Telecom sector organizations, two assistants from the local community were engaged for the questionnaire distribution and collection. The purpose of engaging two locals for such proceedings was to make the whole process smooth as they could easily communicate with the employees and facilitate them with the questionnaire filling. Desired respondents were approached by the permission of management of the concerned organizations. While distributing the questionnaires, assistants were asked to explain participants the purpose of the research and they were also assured about the confidentiality of the information provided by them.

Respondents were given a week's time to respond. Initially, the purpose was to deliver survey questionnaire to as many employees as possible but due to certain limitations, assistants could only contact 200 respondents in all the six organizations. Out of 200 filled questionnaires, only 162 questionnaires were used for the analysis purpose as the rest were not properly filled. This made the total response rate as $81 \%$.

\subsection{Research Instrument}

The items for research instrument were taken from various sources. The variable "Employee participation" is measured on the scale developed by Holter (1965) mentioned in Marchington (1992), but with some amendments. The second independent variable, "Employee relations", is measured on the scale designed by Shockely-Zalabak, Ellis, and Cesaria (2000). This scale was mainly developed to measure the organization trust with some key dimensions in which, 'concern for the employee' was one of the dimensions. To measure the stated employee relations variable, items were taken from that specific "concern for employee" dimension. The same dimension also was used by Odhong (2014) to measure employee relations. To measure "Job involvement", statements were taken from the scale developed by Lodahl and Kejner (1965). For measuring the dependent variable, "Employee performance", items were taken from the scale developed by Schneider and Barlett 
(1968, 1970). This scale was essentially developed to examine the effect of organizational climate on employee performance.

\subsection{Model of the Study}

The following regression model is estimated for this study.

$P M=\beta_{0}+\beta_{1}(E P)+\beta_{2}(E R)+\beta_{3}(J I)+e_{i}$

Where,

$\mathrm{PM}=$ Employee performance, $\mathrm{EP}=$ Employee participation, $\mathrm{ER}=$ Employee relation and $\mathrm{JI}=\mathrm{Job}$ involvement.

\subsection{Reliability Test}

Cronbach's alpha was used to check the inter-item consistency for each of the key study variables. Table 1 presents the reliability test results.

Table 1: Cronbach's alpha

\begin{tabular}{|c|c|c|}
\hline \multicolumn{3}{|c|}{ Reliability analysis } \\
\hline Variables & No. of items & Cronbach's alpha \\
\hline Employees' Performance & 6 & 0.75 \\
\hline Employees' Participation & 6 & 0.77 \\
\hline Employees' Relations & 6 & 0.80 \\
\hline Job Involvement & 7 & 0.81 \\
\hline
\end{tabular}

Note : Total number of items $=25$

If Cronbach's Alpha exceeds the value .70, then the constructed instrument is highly reliable. Thus it can be seen that the reliability of the survey instrument is highly significant that crosses the aforesaid threshold limit.

\section{Analysis of Results}

Table 2 presents the descriptive statistics as well as correlations among dependent and independent variables. The table shows a mean value of employee participation as 3.42, which is moderate, implying that majority of the respondents' responses were in support of employee participation at 5-point Likert scale and these responses deviate .71 from the average responses of the respondents. In addition, employee participation is positively related to employee performance with a correlation value of .547 , which is significant at $1 \%$. Employee relations is also positively related to employee performance with a value of .521 , which is signifi- 
cant at $1 \%$. Moreover, mean value and standard deviation of employee relation are 3.08 and 0.60 respectively. The mean value is near 3 , indicating the above average responses of the respondents in support of employee relations. However, the mean response on the job involvement is 4.15 , which is higher in comparison to the first two variables. For job involvement, the deviation from the mean is .52, which is also less in comparison to the first two variables. The correlation value of job involvement is .576, which is strongly related to employee performance in comparison to employee relations and employee participation. The correlation value of job involvement is also significant at $1 \%$.

Table 2: Descriptive statistics \& Pearson's correlations $\quad \mathrm{N}=162$

\begin{tabular}{|c|c|c|c|c|c|c|}
\hline Variables & Mean & SD & EP & ER & JI & PM \\
\hline EP & 3.42 & 0.71 & 1 & & & \\
\hline ER & 3.08 & 0.60 & $487^{* *}$ & 1 & & \\
\hline JI & 4.15 & 0.52 & $.480^{* *}$ & $.550^{* *}$ & 1 & \\
\hline PM & 3.58 & 0.80 & $.547^{* *}$ & $.521^{* *}$ & $.576^{* *}$ & 1 \\
\hline
\end{tabular}

**. Correlation is significant at the 0.01 level (2-tailed)

Table 3 depicts the model summary results. It is evident from the results that all independent variables have $45.2 \%$ (combined) impact on employee performance. The value of $\mathrm{R}$ square (.452) is high enough to bring changes in the dependent variable.

Table 3: Model Summary ${ }^{\mathrm{b}}$

\begin{tabular}{|c|c|c|c|c|}
\hline Model & $\mathrm{R}$ & R-Square & $\begin{array}{c}\text { Adjusted } \\
\text { R-Square }\end{array}$ & $\begin{array}{c}\text { Standard Error } \\
\text { of the estimate }\end{array}$ \\
\hline 1 & $.672^{\mathrm{a}}$ & .452 & .441 & 3.0018 \\
\hline
\end{tabular}

a. Predictors: (Constant), Job inv., Emp. Part., Emp. Rel.

b. Dependent Variable: Employees' Performance

Table 4 shows the results of model fit, measured by ANOVA (F-test). Since the p-value is less than the level of significance, it is concluded that the fit between dependent and independent variables is significant, implying a good model.

Table 4: Model fit (ANOVA) results

\begin{tabular}{|c|c|c|c|c|c|}
\hline \multicolumn{7}{|c|}{ ANOVA $^{\mathrm{a}}$} \\
\hline Model & Sum of Squares & Df & Mean Square & F & Sig. \\
\hline Regression & 1173.132 & 3 & 391.044 & 43.415 & $.000^{\mathrm{b}}$ \\
\hline Residual & 1423.121 & 158 & 9.007 & & \\
\hline Total & 2596.253 & 161 & & & \\
\hline
\end{tabular}

a. Dependent Variable: Employees Performance

b. Predictors: (Constant), Job involvement ., Employees Participation., Employees Relations 
Table 5 shows the regression results of the study, subject to equation (1). Results indicate a positive and significant impact of employee participation on employee performance. Similarly, employee relations and job involvement are also found to maintain a significant positive relationship with employee performance. All these results are consistent with the hypotheses generated through the literature.

Table 5: Regression results

\begin{tabular}{|c|c|c|c|c|c|c|c|}
\hline \multicolumn{7}{|c|}{ Coefficientsa } \\
\hline & \multicolumn{2}{|c|}{ Unstandardized Coefficients } & \multicolumn{2}{c|}{ Standardized Coefficients } & $\begin{array}{c}\text { Collinearity } \\
\text { Statistics }\end{array}$ \\
\hline & B & Std. Error & Beta & T & Sig. & Tolerance & VIF \\
\hline (Constant) & 1.237 & 1.486 & & .832 & .406 & & \\
\hline EP & .275 & .066 & .293 & 4.161 & .000 & .698 & 1.432 \\
\hline ER & .206 & .077 & .199 & 2.688 & .008 & .633 & 1.579 \\
\hline JI & .291 & .066 & .326 & 4.423 & .000 & .639 & 1.566 \\
\hline
\end{tabular}

a. Dependent Variable: Employees' Performance

The above table reports the values for the regression model as

$P M=1.237+0.275(E P)+0.206(E R)+0.291(J I)+$ error

Multi-collinearity was also checked between independent variables. The variance inflation factor (VIF) for all the independent variables, i.e. employee participation, employee relations, and job involvement are 1.432, 1.579, and 1.566, respectively. Since these values are less than 5 , this shows that there exists no multi-collinearity among independent variables.

\section{Conclusion}

This study attempted to empirically test the relationship between employees' performance and job involvement, employee participation, and employee participation. The data used in this study is perception based, collected from the employees working in the Telecom sector of Kabul. The results confirmed the effect of job involvement on employee performance. Moreover, employee relations and employee participation were found to have significant relationship with employee performance. Results of this study are important for managers in the Telecom sector that non-monetary rewards and the change in their managerial styles from being autocratic to democratic improve employees' performance.

Employee performance is one of the key variables to be considered by any organization to perform effectively. Higher the employee performance, higher the productivity level in the organization, which eventually leads to higher profitability. Managers 
should work on initiating programs and activities to enhance employees' participation, job involvement, and employee relations, which shall ultimately improve employees' performance. Because of the traditional mindsets, Afghan managers do not consider employees' participation, involvement, and employee relations as important factors to improve employee performance. This study may be a good step in this direction.

Following were some limitations faced while conducting the study. Some questionnaires were not properly filled which resulted in missing values. Few employees had some language and literacy problems as they were not able to read and understand English properly. Assistants from local community were hired to help employees with English language, hence resulting in a time consuming procedure. Also, the sample size used in this study is off course small as data were collected from the branches located in Kabul city only. And finally, this research has considered only three variables from the Herzberg two-factor theory model to see their impact on employee performance; however, other variables can also be taken into consideration to see their impact on employee performance for future researches.

This research does not differentiate between employees working in public and private Telecom organizations in Afghanistan. Future researches can be conducted on employees' performance in public and private Telecom organizations separately.

\section{References}

Abbas, Q., \& Yaqoob, S. (2009). Effect of leadership development on employee performance in Pakistan. Pakistan Economic and Social review, 47(2), 269-292.

Ahmed, P. K., \& Rafiq, M. (2003). Internal marketing issues and challenges. European Journal of Marketing, 37(9), 1177-1186.

ALDamoe, F. M. (2015). Human resource management practices on organizational performance in Libya firm. Asian Social Science, 11(23), 51-58.

Armstrong, M., \& Baron, A. (1998). Performance management: The new realities. London: IPD.

Beardwell, J., \& Claydon, J. (2007). Human resource management: A contemporary approach (5 ${ }^{\text {th }}$ ed.). Great Britain, Pearson Education Limited.

Brown, S. P. (1996). A meta-analysis and review of organizational research on job involvement. Psychological Bulletin, 120(2), 235-255.

Collis, D. J., \& Montgomery, C. A. (1995). Competing on resources. Harvard Business Review.

Cummings, L., \& Schwab, D. (1973). Performance in organizations: Determinants and appraisal. Scott Foresman, Glenview: Illionis. 
Ezeani, S. I. (1998). Research methods: A realistic approach. Ibadan: Elohim Publishers.

Graham, H., \& Bennet, R. (1998). Human resource management (9 $9^{\text {th }}$ ed.). Great Britain: Pearson Education Limited.

Hellriegel, D., \& Slocum, J. (1999). Management ( $7^{\text {th }}$ ed.). Cincinnati, OH: South-Western College Publishing.

Holter, H. (1965). Attitudes towards employee participation in company decision making process. Human relations, 18(1), 297-321.

Kanungo, R. N. (1982). Measurement of job and work involvement. Journal of Applied Psychology, 67(3), 341-349.

Lavelle, J., Gunnigle, P., \& McDonnell, A. (2010). Patterning employee voice in multinational companies. Human Relations, 63(3), 395-418.

Lawler, E. E., Mohrman. S., \& Ledford, G. (1992). Employee involvement and total quality management: Practices and results in Fortune 100 companies. San Francisco: Jossey- Bass

Likert, R. L. (1961). The human organization. New York: McGraw-Hill.

Locke, E. A., \& Schweiger, D. M. (1979). Participation in decision-making: One more look. Research in Organizational Behavior, 1(10), 265-339.

Lodahl, T., \& Kejner, M. (1965). The definition and measurement of job involvement. Journal of Applied Psychology, 49(1), 24-33.

Luthans, F. (2005). Organisational behavior (10 ${ }^{\text {th }}$ ed.). New York: McGraw-Hill.

Marchington, M. (1992). Responses to participation at work. Gower: Farnborough

Markey, R. (2001). Global patterns of participation. In R. Markey, P. Gollan, A. Hodgkinson, A. Chouraqui \& U. Veersma (eds.). Models of employee participation in a changing global environment: diversity and interaction (pp. 3-22). Aldershot: Avebury.

Marshall, C. R., \& Ward, P. D. (1996). Sudden and gradual molluscan extinctions in the latest Cretaceous of western European Tethys. Science, 274(5291), 1360-1363.

Moorhead, G., \& Griffin, R. (1989). Organizational behavior (2 ${ }^{\text {nd }}$ ed.). Boston: Houghton Mifflin Company.

Mujtaba, B. G., \& Kaifi, B. A. (2008). Afghan and American professionals' leadership orientation toward tasks and relationships: Are there tendencies toward convergence or divergence? Fortune Journal of International Management, 5(1), 107-125.

Mwita, J. I. (2000), Performance management model: A system-based approach to system quality. The International Journal of Public Sector Management, 13(1), 19-37. 
Odhong, A. E. \& Omolo, J. (2014). An analysis of the factors affecting employee relations in the flower industry in Kenya: A case of Waridi Ltd, Athi River. Internatoinal Journal of Business and Socical Science, 5(11), 147-160.

Padilla-Velez. D. (1993). Job satisfaction of vocational teachers in Puerto Rico. The Ohio State University.

Panagiotakopoulos, A. (2013). The impact of employee learning on staff motivation in Greek small firms: The employees' perspective. Developing and Learning in Organization: An International Journal, $27(2), 13-15$.

Paullay, I. M., Alliger, G. M., Stome, R., \& Eugene, F. (1994). Construct validation of two instruments designed to measure job involvement and work centrality. Journal of Applied Psychology, 79(2), 224-228.

Paulus, P. B., Seta, C. E., \& Baron, R. A. (2006). Effective human relation. A guide to be people at work (3 ${ }^{\text {rd }}$ ed.). Boston: Prentice Hall

Pfeffer, J. (1994). Competitive advantage through people. Boston: Harvard Business School Press.

Shockley-Zalabak, P., Ellis, K., \& Cesaria, R. (2000).Measuring organizational trust: A diagnostic survey and international indicator. San Francisco: International Association of Business Communicators.

Schneider, B., \& Bartlett, J. (1968). Individual differences and organizational climate I. The research plan and questionnaire development. Personnel Psychology, 21(3), 323-333.

Schneider, B., \& Bartlett, J. (1970). Individual differences and organizational climate II: Measurement of organizational climate by the multi-trait, multi-rater matrix. Personnel Psychology, 23(4), 493-512.

Soong, S. W. (2000). The study on the devotion and job satisfaction of adults' participation in volunteer services. Taiwan: National Kaohsiung Normal University

Wagner, A. J. (1994). Participation's effects on performance and satisfaction: A reconsideration of research evidence. Academy of Management Review, 19(2), 312-330.

Wilpert, B. (1998). Participation: A view from psychology. In E. P. Frank Heller (Eds.), An overview of organizational participation: myth and reality (pp. 40-64). New York: Oxford University Press.

Whetten, D. A., \& Cameron, K. S. (1998). Developing management skills (3 ${ }^{\text {rd }}$ ed.). New York: Harper Collins. 


\section{Appendix}

List of Telecommunication companies and number of respondents from each company

\begin{tabular}{|c|c|c|}
\hline \multicolumn{3}{|c|}{ Table A1: List of companies and number of participant } \\
\hline Company name & $\begin{array}{c}\text { Survey questionnaires distributed (No. } \\
\text { of participants in total) }\end{array}$ & $\begin{array}{c}\text { No. of survey Questionnaires } \\
\text { used for the analysis }\end{array}$ \\
\hline AWCC & 38 & 31 \\
\hline AFTEL & 32 & 24 \\
\hline ROSHAN & 34 & 25 \\
\hline MTN & 29 & 26 \\
\hline Etisalat & 36 & 32 \\
\hline Wasel Telecom & 31 & 24 \\
\hline Total & 200 & 162 \\
\hline
\end{tabular}

\section{Survey Instrument}

\begin{tabular}{|c|c|c|c|c|c|}
\hline \multicolumn{6}{|l|}{ Employee Participation } \\
\hline & SA & A & $\mathrm{N}$ & $\mathrm{DA}$ & SDA \\
\hline I am always asked to complete employee surveys & 5 & 4 & 3 & 2 & 1 \\
\hline $\begin{array}{l}\text { I participate in an employee suggestion programs and meetings for } \\
\text { giving suggestions and ideas for improvement }\end{array}$ & 5 & 4 & 3 & 2 & 1 \\
\hline My organization gives me opportunity of job rotation & 5 & 4 & 3 & 2 & 1 \\
\hline Organization provides me training programs for learning & 5 & 4 & 3 & 2 & 1 \\
\hline $\begin{array}{l}\text { I am always informed about overall workplace Performance or any } \\
\text { changes to workplace environment }\end{array}$ & 5 & 4 & 3 & 2 & 1 \\
\hline $\begin{array}{l}\text { I have the opportunity of independent thought and actions In my } \\
\text { job. }\end{array}$ & 5 & 4 & 3 & 2 & 1 \\
\hline \multicolumn{6}{|l|}{ Employee Relations } \\
\hline 1- At my company grievances are handled fairly & 5 & 4 & 3 & 2 & 1 \\
\hline 2- Recruitment is handled fairly & 5 & 4 & 3 & 2 & 1 \\
\hline 3- All employees have equal chance of promotion & 5 & 4 & 3 & 2 & 1 \\
\hline 4- Disciplinary processes \& procedures are handled fairly. & 5 & 4 & 3 & 2 & 1 \\
\hline 5- Management has confidence on staff & 5 & 4 & 3 & 2 & 1 \\
\hline 6- There is high level of discrimination in my Organization (R) & 5 & 4 & 3 & 2 & 1 \\
\hline \multicolumn{6}{|l|}{ Job Involvement } \\
\hline
\end{tabular}




\begin{tabular}{|c|c|c|c|c|c|c|}
\hline $\begin{array}{c}\text { 1- I have very strong ties with my present job this would be difficult } \\
\text { to break }\end{array}$ & 5 & 4 & 3 & 2 & 1 \\
\hline $\begin{array}{c}\text { 2- I feel relaxed when it is time to go } \\
\text { 3- Most of my personal goals are job oriented }\end{array}$ & 5 & 4 & 3 & 2 & 1 \\
\hline 4- I like everything about my job & 5 & 4 & 3 & 2 & 1 \\
\hline 5- I wait impatiently for holidays & 5 & 4 & 3 & 2 & 1 \\
\hline $\begin{array}{c}\text { E- For me the best form of relaxation is doing my job } \\
\text { 7- I am not willingly devote my free time to job }\end{array}$ & 5 & 4 & 3 & 2 & 1 \\
\hline \multicolumn{2}{|c|}{5} & 4 & 3 & 2 & 1 \\
\hline $\begin{array}{c}\text { My present job gives me the opportunity to enhance my Perfor- } \\
\text { mance on job }\end{array}$ & 5 & 4 & 3 & 2 & 1 \\
\hline $\begin{array}{c}\text { My present job has a direct impact on achieving the Organizational } \\
\text { objectives }\end{array}$ & 5 & 4 & 3 & 2 & 1 \\
\hline $\begin{array}{c}\text { My job performance outcomes are consistent with the goals of the } \\
\text { organization }\end{array}$ & 5 & 4 & 3 & 2 & 1 \\
\hline $\begin{array}{c}\text { My good performance on job is rewarded financial terms } \\
\text { My good performance on job is given formal appreciation by the } \\
\text { higher ups }\end{array}$ & 5 & 4 & 3 & 2 & 1 \\
\hline \begin{tabular}{c} 
The job performance evaluation system is objective \\
\hline
\end{tabular} & 5 & 4 & 3 & 2 & 1 \\
\hline
\end{tabular}

